\title{
EFFECTS OF HIGH-CARBOHYDRATE PRODUCTS CONSUMPTION ON POSTPRANDIAL GLYCEMIA IN RUNNERS
}

\section{WPŁYW SPOŻYCIA PRODUKTÓW BOGATYCH W WĘGLOWODANY NA GLIKEMIĘ POPOSIŁKOWĄ WŚRÓD BIEGACZY}

\author{
Jakub Czaja ${ }^{1(\mathrm{~A}, \mathrm{~B}, \mathrm{C}, \mathrm{D}, \mathrm{E}, \mathrm{F}, \mathrm{G})}$, Marta Stachowicz $^{2(\mathrm{C}, \mathrm{D}, \mathrm{E}, \mathrm{F})}$, Anna Lebiedzińska ${ }^{1,2(\mathrm{~A}, \mathrm{D}, \mathrm{G})}$
}

\author{
${ }^{1}$ Pope John Paul II State School of Higher Education in Biała Podlaska, Poland \\ ${ }^{2}$ Medical University Of Gdańsk, Poland
}

Authors' contribution Wkład autorów:

A. Study design/planning zaplanowanie badań B. Data collection/entry zebranie danych C. Data analysis/statistics dane - analiza i statystyki D. Data interpretation interpretacja danych E. Preparation of manuscript przygotowanie artykułu F. Literature analysis/search wyszukiwanie $\mathrm{i}$ analiza literatury G. Funds collection zebranie funduszy
Tables: 0

Figures: 3

References: 23

Submitted: 2017 Oct 16

Accepted: 2017 Dec 01

\section{Summary}

Background. Running causes that people become more and more willing to engage in physical activity. It is an valid exercise that significantly decreases postprandial glycemia. The higher the training load, the more important it is to complement nutrients necessary for organism regeneration. Modern food industry provides many products that can help in resynthesis of muscle glycogen. The study presents a mutual correlation between consuming high-carbohydrate products with and without having exercise afterwards and the shape of the blood glucose curve.

Material and methods. Nine healthy and hard training male adult athletes participated in 2-part (P1 and P2) research: P1 with, and P2 without run. After the run, the athletes had a specified meal, after which capillary blood glucose test was taken for P1 before the run and for both groups 2-3 min, at 30, 60, 90 and 120 min after the meal.

Results. The comparison of the area under the curve (AUC) at rest and after $1 \mathrm{hr}$ run showed statistically significant variations after every 30 minutes period and in the overall AUC. The smallest AUC occurred after consuming chips and spinach pasta and the highest after potatoes, white and brown rice.

Conclusions. Physical activity does not change the way glucose is released into the blood, but it lowers postprandial glycemia, especially after 30-90 minutes after training completion. This study indicates that consuming potatoes and rice leads to the highest rate of muscle glucose uptake and further faster glycogen re-synthesis after the run. Accordingly, these products can be a good choice for athletes having a short break between training bouts.

Keywords: postprandial glycemia, endurance, running, dietary carbohydrates, glycemic index

\section{Streszczenie}

Wprowadzenie. W ostatnich latach bieganie stało się bardzo popularną formą aktywności fizycznej, która skutecznie obniża glikemię poposiłkową. Wraz ze wzrostem obciążeń treningowych, nabiera znaczenia odpowiednie uzupełnienie składników odżywczych, w celu zapewnienia optymalnej regeneracji. Współczesny przemysł spożywczy dostarcza wielu produktów mogących pomóc $w$ resyntezie zapasów glikogenu mięśniowego. Celem pracy jest określenie wzajemnej korelacji między spożyciem produktów bogatych w węglowodany po lub bez treningu oraz kształtem krzywej poposiłkowego stężenia glukozy we krwi.

Materiał i metody. Dziewięciu zdrowych, dobrze wytrenowanych biegaczy uczestniczyło w badaniu stężenia glukozy w krwi kapilarnej po 2-3, 30, 60, 90 i 120 minutach po określonym posiłku. W pierwszej części (P1) spożycie był poprzedzone treningiem biegowym. W części drugiej (P2) pobranie pokarmu nie odbywało się po wysiłku fizycznym.

Wyniki. Porównanie pola pod krzywą stężenia (AUC) glukozy we krwi w warunkach odpoczynku i po godzinie biegu pokazało znaczące różnice zarówno w całkowitym AUC, jak i w ilości glukozy po 30 minutach od spożycia posiłku. Najmniejsze AUC wykazano po spożyciu frytek i makaronu ze szpinakiem, a największe po gotowanych ziemniakach oraz białym i brązowym ryżu.

Wnioski. Wysiłek fizyczny nie wpływa na sposób uwalniania glukozy do krwi po posiłku, ale wpływa na obniżenie glikemii poposiłkowej, szczególnie po 30-60 minutach od zakończenia treningu. Uzyskane wyniki mogą sugerować, że spożycie ryżu i ziemniaków po bieganiu może przyczyniać się do szybszej resyntezy glikogenu mięśniowego, co może być szczególnie korzystne w przypadku krótkich odstępów czasu między kolejnymi sesjami treningowymi.

Słowa kluczowe: glikemia poposiłkowa, wytrzymałość, bieganie, produkty bogate $\mathrm{w}$ węglowodany, indeks glikemiczny

Czaja J, Stachowicz M, Lebiedzińska A. Effects of high-carbohydrate products consumption on postprandial glycemia in runners. Health Prob Civil. 2018; 12(1): 64-70. https://doi.org/10.5114/hpc.2018.74192

Address for correspondence / Adres korespondencyjny: Marta Stachowicz, Department of Food Sciences, Medical University Of Gdańsk, Al. Gen. J. Hallera 107, 80-416 Gdańsk, Poland, e-mail: 1234@gumed.edu.pl, phone: +4858349 1089

Copyright: (C) Pope John Paul II State School of Higher Education in Biała Podlaska, Jakub Czaja, Marta Stachowicz, Anna Lebiedzińska. This is an Open Access journal, all articles are distributed under the terms of the Creative Commons Attribution-NonCommercial-ShareAlike 4.0 International (CC BY-NC-SA 4.0) License (http://creativecommons.org/licenses/by-nc-sa/4.0/), allowing third parties to copy and redistribute the material in any medium or format and to remix, transform, and build upon the material, provided the original work is properly cited and states its license. 


\section{Introduction}

Grain and cereal-grain food products constitute an essential part of the human diet by providing a high proportion of carbohydrates, proteins, fats, dietary fibre, B-group vitamins and minerals [1]. Scientists from Harvard School of Public Health (2011) recommend physical activity and weight control as the most effective ways of preventing metabolic diseases. The other group of foods enumerated by the nutrition pyramid which are essential to human health includes vegetables, fruits, healthy oils and wholegrain products [2].

As indicated by Edwards et.al., the structural integrity of wheat endosperm has greatinfluence on postprandial metabolism. An adequate amount of grain and cereal-grain food in one's diet is one of the factors used for treatment and prevention of diabetes, cardiovascular diseases, colon cancer and too high level of cholesterol in blood [3]. Furthermore, consumption of adequate carbohydrates can also affect people's emotions and mood [4]. Lacoppidan et al. found that Nordic diet, rich in fish, cabbage, rye bread and oatmeal, is significantly associated with lower risk of type 2 diabetes [5]. Further, whole grain products contain significant amounts of fibre, which is shown to decrease insulin and peptide $\mathrm{C}$ levels and reduce the percentage of small and dense LDL [6].

Besides, Bailey et al. showed that going for a light-intensity walk after finishing a meal has a positive influence on postprandial glycemia. Thus, proper diet, in connection with physical activity, has a beneficial impact on insulin and glucose levels in the blood after the meal and can reduce cardio-metabolic disease risk [7].

Presently, there is a new trend towards increasing the number of covered kilometres as well as intensifying training and quantity of training sessions per day. Many factors play a significant role in the recovery process after highly intensive training. These include types of administered exercise, the meal ingestion-time, the number of ingested carbohydrates (CHO), as well as the glycemic response to the ingested food or supplements. Accordingly, consuming food products or dietary supplements rich in carbohydrates is recommended to achieve the most optimal body's recovery [8]. There are also suggestions to add proteins to CHO, which might augment the process of recovery by increasing the rate of glycogen synthesis $[9,10]$.

Modern food industry supplies athletes with numerous products. It is essential to choose a proper source of carbohydrates, tailored to the individual's needs.

Ormsbee et al. outline that the most common source of delivering carbohydrates for the athletes are food products such as cereals, pasta, rice, groats, potatoes and others; however, liquids and solid forms of different supplements are used as well. Also, the degree of processing of food products significantly affects the glycemic index [11].

The purpose of this study was to determine the influence of ingesting different food products on the immediately after exercise glycemic response.

\section{Material and methods}

\section{Participants}

Nine healthy male adult athletes who trained extensively (at least $100 \mathrm{~km} / 6$ training sessions/ week) took part in the research. All of them were in the same phase of training, i.e. mesocycle. Each of them was precisely informed about the aim of the study, the research proceeding, their function in the study as well as the possible consequences as indicated by the protocol of Bioethical Commission of Gdansk Medical University No NKEBN/14/2008 of February the $12^{\text {th }} 2008$. Then, a voluntary participation agreement was signed the parties the runners and the Gdansk Medical University was signed by the parties simultaneously.

\section{Carbohydrate products}

Pure glucose powder and ten selected high-CHO products with a different glycemic index (GI) were examined according to how frequently they were consumed by the participants. The chosen products included three different types of pasta and rice, two types of groats, one sort of chips and potatoes. To conduct a quantitative analysis of ash, water, proteins, fats and carbohydrates in the chosen products, the AOAC method was used for quantification. The dietary fibre content in the selected products was estimated according to "Tables of food composition and nutritive value" [12].

The analy tical scale (XA RADWAG) was used to measure suitable product portions $( \pm 0,1 \mathrm{~g})$. The food samples were prepared according to the manufacturer's recommendations. The products were served after having been washed, rinsed with water and washed again. To facilitate the consumption $1 \mathrm{~g}$ of mixed spices (equal parts of oregano, basil, granulated garlic, thyme, Provencal herbs and salt) was added to each of the sample. The glucose solution contained $50 \mathrm{~g}$ of glucose powder and $450 \mathrm{~mL}$ of mineral water. 


\section{Preparation of tested products}

All of the runners who took part in the research performed one-hour run at the intensity of $70-75 \%$ of maximal heart rate (HRmax) estimated by equation proposed by Tanaka et al. [13]. To avoid individual differences, the estimated HRmax was compared to the HRmax recorded during the competitions held in the previous 3 months. HR was measured by two different electronic devices with GPS technology (Garmin Forerunner 305 and Polar RS300X). The runs were performed in natural conditions and on the same flat course (0-5 AMSL) with similar weather conditions, i.e. $4-6{ }^{\circ} \mathrm{C}$ degrees.

\section{Postprandial glycemia measurement}

The postprandial glycemia changes were determined by using the Accu-Check Active glucometer (Roche), in capillary blood samples taken from finger-tips. The fingers were cleaned with the sterile swabs using salicylic alcohol before each sample collection. The single-use needles were applied for every single prick and measurements were conducted using the second blood drop. The double-check was applied in case of suspiciously high or low results to eliminate any mistakes during the procedure.

\section{Research design}

The study lasted from November 2009 until January 2010. The athletes had postprandial glycemia measured after the run or at rest every 2 weeks. Figure 1 presents the scheme of the research proceedings.

\section{AFTER 1-HOUR RUN AT 70\% HRmax}

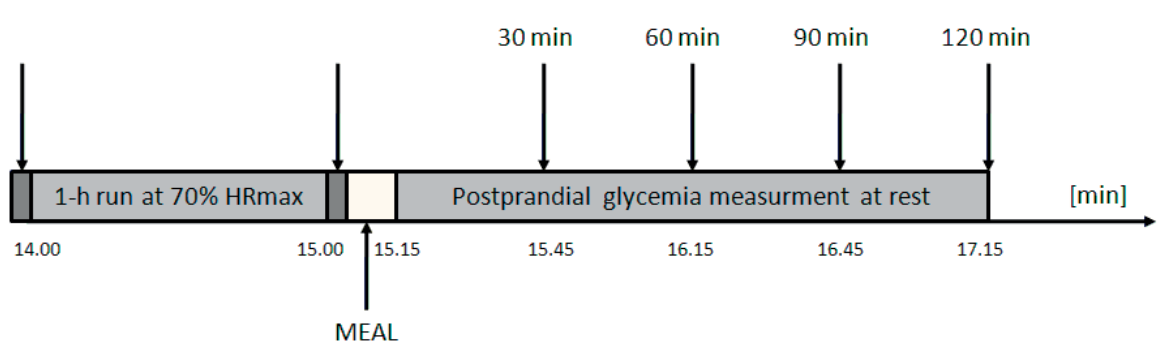

AT REST

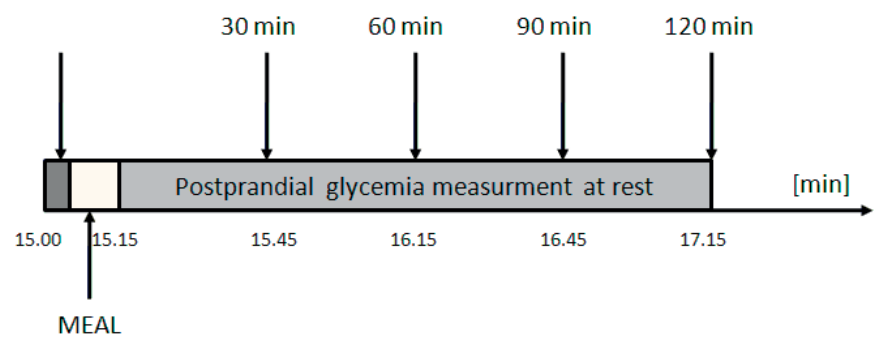

Figure 1. Scheme of the research procedure

The first part (P1) of the research was to have a meal with $400-500 \mathrm{~mL}$ of mineral water just after the run and the other part (P2) was administered without the run. The research started at $2 \mathrm{pm}$ or $3 \mathrm{pm}$. The athletes could not have any meals during the $2,5 \mathrm{~h}$ preceding the test, and the last meal had to have low or moderate GI. They were asked to eat the same food products on the day the measurements were taken. Glycemic measurements for P1 were made before the run and for both groups $2-3 \mathrm{~min}$, at 30, 60, 90 and $120 \mathrm{~min}$ after the meal.

\section{Statistical analysis}

All the gathered data were analysed to detect any changes in postprandial glycemia. The Mann-Whitney $\mathrm{U}$ test was used to calculate the differences between blood glucose value and the area under the curve values (AUC) at rest and after the run. Statistica software (version 8.0, StatSoft Polska Sp. z 0.o., Warsaw, Poland) was applied to do all statistical analyses. The assumed significance level was 0.05 . 


\section{Results}

Blood glucose concentrations changes are presented in figure 2 .

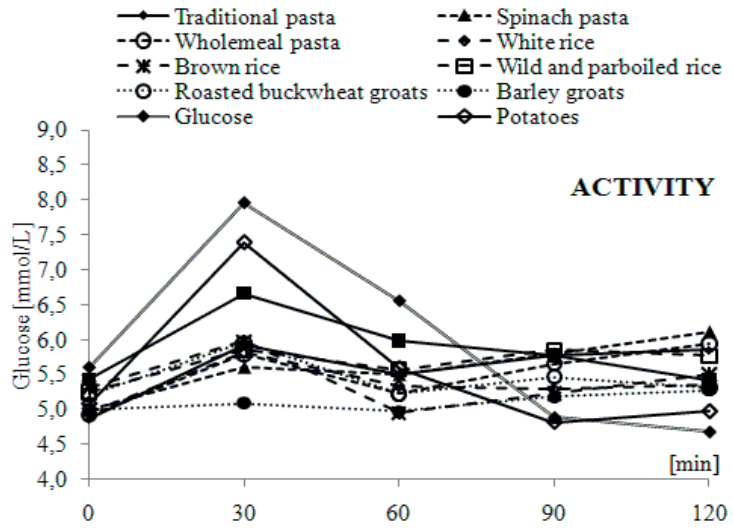

A.

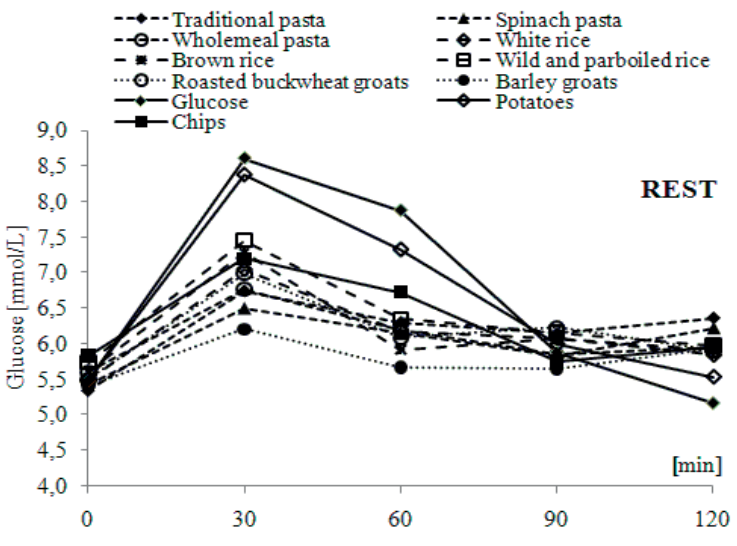

B.

Figure 2. Postprandial glucose after eating 11 products without doing exercise (A) and after doing exercise (B)

\section{The glycemic profile}

There were several different postprandial glycemic profiles observed during the course of the study. The peak of the glucose values appeared 30 minutes after the consumption of all the examined products. The postprandial glycemic values were also estimated at rest.

\section{The highest glycemia}

The highest level of blood glucose after a run was observed in the first 30 minutes after eating most of the tested products. The glucose values peak occurred 120 minutes after having wholemeal pasta or barley groats. As for the consumption of wild and parboiled rice after exercising, similar results were obtained with peak glucose values achieved at 30 minutes and 90 minutes. The highest average blood glucose concentrations at rest and after one-hour run were visible after the consumption of $10 \%$ glucose solution $(8.60 \mathrm{mmol} / \mathrm{L}$ and 7.96 $\mathrm{mmol} / \mathrm{L}$ respectively) and potatoes $(8.38 \mathrm{mmol} / \mathrm{L}$ and $7.39 \mathrm{mmol} / \mathrm{L}$ respectively).

\section{The lowest glycemia}

The lowest glycemia values at rest (P2) were observed 90 minutes after eating three kinds of pasta, barley groats and chips; and then 120 minutes after eating three kinds of rice, buckwheat groats, glucose and potatoes. The lowest values of postprandial glycemia after a run were noticed 60 minutes after consuming a vast majority of the examined products except for white rice and potatoes (90-minute postprandial glycemia) and chips and glucose (120-minute postprandial glycemia). The lowest average blood glucose concentrations in both cases were recorded for $10 \%$ glucose solution and potatoes.

The glucose values stayed above the initial level (baseline) at rest (P2) for 120 minutes after the mean except when chips were consumed (90 minutes after consumption) and glucose (120 minutes after consumption), which have the results below the baseline. In P1, the results of glucose values for brown rice and barley groats stayed under the baseline at 60 minutes, and 90 minutes after the meal.

\section{Glycemia in rest conditions and after running}

One hour-run decreased postprandial glycemia when compared to that at rest. Statistically significant variations $(\mathrm{p}<0.05)$ were observed after consuming most of the tested products. There was no statistically significant variation in postprandial glycemia found after having chips and glucose; however, when compared to other conditions, the postprandial glycemia decreased within one hour.

\section{AUC comparison}

The determined AUC value for all the examined products is visible in Figure 3. The research has shown that the highest AUC at 30, 60, 90 minutes and overall at rest conditions occurred after consuming glucose and potatoes. 


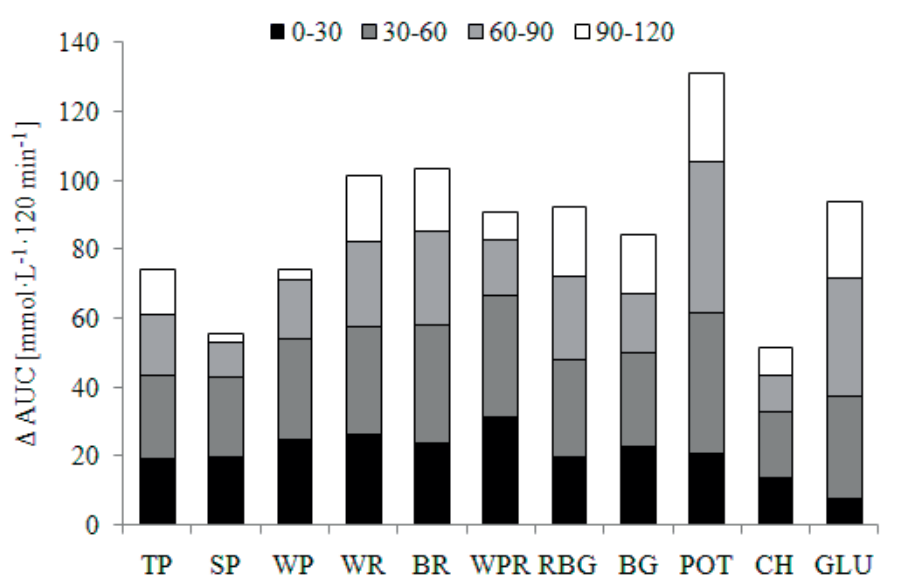

TP - traditional pasta; SP - spinach pasta; WP - wholemeal pasta; WR - white rice; BR - brown rice; WPR - wild and parboiled rice; BG - roasted buckwheat groats; BG - barley groats; POT - potatoes CH - chips; GLU - glucose

Figure 3. Differences between AUC value at rest and after 1-h run at 75\% $\mathrm{HR}_{\max }$ at 30, 60, 90 and 120 minutes after consuming the examined products portions

Considering the first 30 minutes, the highest $\triangle \mathrm{AUC}$ was the consequence of having wild and parboiled rice while, at the consecutive three thirty minutes periods, the highest $\Delta$ AUC was found after consuming potatoes. Also, the potatoes intake resulted in the highest overall $\triangle \mathrm{AUC}$.

The intake of glucose in the first 30 minutes, chips in the second and spinach pasta in the third and forth 30 minutes time resulted in the smallest $\triangle \mathrm{AUC}$ value. The smallest overall $\triangle \mathrm{AUC}$ was also achieved after consuming chips and spinach pasta. The statistically significant differences $(\mathrm{p}<0.05)$ of $\Delta$ AUC in each 30 minute time period and overall $\triangle \mathrm{AUC}$ were obtained after seven examined products, excluding spinach pasta, potatoes, chips and glucose.

\section{Discussion}

\section{Profiles of postprandial glycemia}

The research showed that the profiles of postprandial glycemic response to the examined products at rest were similar to those indicated by other authors $[10,14,15]$.

Stevenson et al. presented a 24-hour glycemic profile obtained after breakfast and lunch which based on two different carbohydrates products and showed that pasta gives higher and lower peak faster than in our study [16]. Such a discrepancy might result from a higher carbohydrates content in a single portion as well as an addition of an apple and pear juice that contains simple carbohydrates. In fact, Stevenson et al. proved that the initial glycemic values before a low-GI breakfast (at the fasting state) and a low-GI lunch with a three-hour gap in-between were similar and the peak glucose appeared in the first 30 minutes time. However, the shape of the Stevenson's research curves supports the general solidity of our study [16].

\section{Effect of training on postprandial glycemia}

One-hour run at the intensity of $70-75 \%$ of HRmax caused changes in the muscle and liver glycogen content, which resulted in decreased postprandial glycemia when compared to that at rest. The recent research indicates that aerobic exercises which increase the glucose uptake during the activity, simultaneously increase the tissue sensitivity to insulin several hours after the exercise cessation. As Richter and Hargreaves' study demonstrates, contraction-stimulated muscle glucose uptake results from increasing GLUT-4 membrane translocation. It also depends on the actual glycogen content [17]. Furthermore, as several other studies indicate, exercise-induced glycogen depletion stimulates several insulin-independent intracellular mechanisms. Although the signalling pathways underlying GLUT-4 surface translocation are not yet entirely clear, some mechanisms involving AMPactivated protein kinase (AMPK), calcium, p38 mitogen-activated protein kinase (p38 MAPK), nitric oxide synthase (NOS) or bradykinin have been proposed [18]. The effects of exercise-stimulated glucose uptake are extended to the first rapid phase of recovery lasting for about 30 to 60 minutes, which allows for fast glycogen synthesis through the insulin-independent pathways. According to Ivy and Kuo, the provision of carbohydrates 
after exercise rapidly increases the insulin concentration and also starts the second insulin dependent phase of recovery with further GLUT-4 translocation and glycogen synthesis [19]. This may explain lower glycemia values after one-hour run observed in our study.

Ivy recommended consuming $\mathrm{CHO}$ immediately after exercise cessation because of faster glycogen resynthesis in the first hours [20]. This effect may additionally be multiplied by an intake of high-GI products[10].

\section{Proper selection of high-carbohydrate products for athletes}

Our study showed that the consumption of specific products, like potatoes, white or brown rice provides easily digestible carbohydrates and should be recommended after training especially if the recovery period between the following sessions is short. Different sorts of pasta, wild or parboiled rice as well as buckwheat and barley groats should also be consumed. In order to make sure that the proper recovery has been obtained by athletes, a long enough gap between the following sessions is recommended. Despite high glycemic values, consuming chips had also resulted in the lowest $\triangle$ AUC. This is probably due to the technological process and their nutritive elements content. Chips have high-fat content, which might have an adverse effect on glucose release and absorption of some carbohydrates. Processed foods may change postprandial glycemia achieved consuming meals based on corn, rice or potatoes, as demonstrated by Brand et al. [21]. Besides as Björck et al. show, changes in glycemic response can also be caused by amylase and amylopectin content in saliva [22].

A very low $\triangle$ AUC observed at the first 30 minutes after $10 \%$ glucose solution consumption might indicate faster glucose blood absorption than glucose muscle uptake.

Our study involved only male athletes, but Folch et al. demonstrated similar results for both sexes [23]. Accordingly, because of higher glycemic values and $\triangle \mathrm{AUC}$ after potatoes intake, white or brown rice are recommended, as they decrease glycemic volume and facilitate $\mathrm{CHO}$ absorption. All this may ensure proper recovery of athletes.

\section{Conclusions}

It was observed that high-CHO products result in a typical postprandial glycemia profile with the glucose values peak visible in the first 30 minutes after consumption at rest. Physical activity decreases postprandial glycemia. It seems crucial to choose an appropriate source of carbohydrates adapted for individual needs. A variety of available cereal products allows for adjusting the best quality of carbohydrates to the type and intensity of particular physical activity. Athletes who take a short break between subsequent training bouts should pay attention to rice and potatoes as products that ensure high muscle glucose uptake and faster glycogen re-synthesis. Finally, physically active people should beware of consuming pasta and chips because they cause slower glucose blood release and muscle glucose uptake.

\section{Acknowledgements}

This paper was supported by Ministry of Science and Higher Education of Poland (Project Grant N N404 047036). The research was conducted on human volunteers, and it was approved by the Biotechnical Commission of Gdansk Medical University No NKEBN/14/2008 of February the $12^{\text {th }} 2008$. Written permission was obtained from all participants before inclusion in the trial.

\section{References:}

1. Lebiedzińska A, Szefer P. 2006. Vitamins B in grain and cereal-grain food, soy-products and seeds. Food Chem. 2006; 95(1): 116-122. https://doi.org/10.1016/j.foodchem.2004.12.024.

2. Harvard School of Public Health Recommendation 2011 [Internet]. Available from www.health.harvard.edu [Cited 2017 May 12].

3. Edwards CH, Grundy MML, Grassby T, Vasilopulou D, Frost GS, Butterworth PJ, et. al. Manipulation of starch bioaccessibility in wheat endosperm to regulate starch digestion, postprandial glycemia, insulinemia, and gut hormone responses: a randomized controlled trial in healthy ileostomy participants. Am. J. Clin. Nutr. 2015; 102(4): 791-800. https://doi.org/10.3945/ajcn.114.106203.

4. Jaworski M, Szatańska MI, Sawicka S. The relationship between emotional state and the consumption of foods rich in carbohydrates by young adults. Health Prob Civil. 2016; 10(2): 10-19.

https://doi.org/10.5114/hpc.2016.59628. 
5. Lacoppidan SA, Kyrø C, Loft S, Helnæs A, Christensen J, Plambeck Hansen C, et al. Adherence to a healthy Nordic food index is associated with lower risk of type-2 diabetes- the Danish diet, Cancer and health cohort study. Nutrients. 2015; 7(10): 8633-8644. https://doi.org/10.3390/nu7105418.

6. Banuls C, Rovira-Llopis S, Monzó N, Sola E, Viadel B, Victor VM, et al. The consumption of bread enriched with dietary fibre and L-carnityne improves glucose homeostasis and insulin sensitivity in patients with metabolic syndrome. J. Cereal Sci. 2015; 64: 159-167. http://dx.doi.org/10.1016\%2Fj.jcs.2015.05.008

7. Bailey DP, Locke ChD. Breaking up prolonged sitting with light-intensivity walking improvez postprandial glycemia, but breaking up sitting with standing does not. J. Sci. Med. Sport. 2015;18(3): $194-298$. https://doi.org/10.1016/j.jsams.2014.03.008.

8. Schröder S, Fischer A, Vock Ch, Böhme M, Schmelzer C, Döpnerm M, et al. Nutrition concepts for elite distance runners based on macronutrient and energy expenditure. J. Athl. Train. 2008; 43(5): 489-504. https://doi.org/10.4085/1062-6050-43.5.489.

9. Zawadzki KM, Yaspelkis BB, Ivy JL. Carbohydrate-protein complex increases the rate of muscle glycogen storage after exercise. J. Appl. Physiol. 1992; 72(5): 1854-1859.

10. Brown LJS, Midgley AW, Vince RV, Madden LA, McNaughton LR. High versus low glycemic index 3-h recovery diets following glycogen-depleting exercise has no effect on subquent 5-km cycling time trial performance. J. Sci. Med. Sport. 2013; 16(5): 450-454. https://doi.org/10.1016/j.jsams.2012.10.006.

11. Ormsbee MJ, Bach ChW, Baur DA. Pre-Exercise Nutrition: The Role of Macronutrients, Modified Starches and Supplements on Metabolism and Endurance Performance. Nutrients. 2014; 6(5): 1782 -1808. https://doi.org/10.3390/nu6051782.

12. Kunachowicz H, Nadolna I, Przygoda B, Iwanow K. Tables of food composition and nutritive value. Warszawa: PZWL; 2005 (in Polish).

13. Tanaka H, Monahan KG, Seals DE. Age-predicted maximal heart rate revisited. J. Am. Coll. Cardiol. 2001; 37(1): 153-156.

14. Brand-Miller JC, Stockman K, Atkinso, F, Petocz P, Denyer G. Glycemic index, postprandial glycemia, and the shape of the curve in healthy subjects: analysis of a database of more than 1000 foods. Am. J. Clin. Nutr. 2009; 89(1): 97-105. https://doi.org/10.3945/ajcn.2008.26354.

15. Jacobs LCA, Perry, TL, Rose MC, Rehrer NJ. The effect of exercise on glicemic and insulinemic response to two beverages of differing glycemic index. Med. Sport. 2006; 13(4): 239-244.

https://doi.org/10.2478/v10036-009-0037-y.

16. Stevenson E, Williams C, Mash LE, Phillips B. Nute M. Influence of high-carbohydrate mixed meals with different glycemic indexes on substrate utilization during subsequent exercise in women. Am. J. Clin. Nutr. 2006; 84(2): 354-360.

17. Richter EA, Hargreaves M. Exercise, GLUT4, and skeletal muscle glucose uptake. Physiol. Rev. 2013; 93(3): 993-1017. https://doi.org/10.1152/physrev.00038.2012.

18. Yavari A. Mechanisms of exercise-induced glucose uptake: evidences and hypothesis. Res. J. Biol. Sci. 2008; 3(10): 1208-1217.

19. Ivy JL, Kuo CH. Regulation of GLUT4 protein and glycogen synthase during muscle glycogen synthesis after exercise. Acta Physiol. Scand. 1998; 162(3): 295-304. https://doi.org/10.1046/j.1365-201X.1998.0302e.x

20. Ivy JL. Regulation of muscle glycogen repletion, muscle protein synthesis and repair following exercise. J. Sports. Sci. Med. 2004; 3(3): 131-138.

21. Brand JC, Nicholson, PL, Thorburn, AW, Truswell SA. Food processing and glycemic index. Am. J. Clin. Nutr. 1985; 42(6): 1192-1196.

22. Björck I, Granfeldt Y, Liljeberg H, Tovar J, Asp NG. Food properties affecting the digestion and absorption of carbohydrates. Am. J. Clin. Nutr. 1994; 59(3 Suppl): 699-705.

23. Folch N, Peronnet F, Massicotte D, Chaarpentier S, Lavoie C. Metabolic response to large starch meal after rest and exercise: comparison between men and women. Eur. J. Clin. Nutr. 2003; 57(9): 1107-1115. 